\title{
A marinha destronada: ou a famigerada São Vicente derrotada pela Rochela paulista. A afirmação de São Paulo como cabeça de capitania (1681-1766).
}

\author{
The seashore overthrown: or the notorious São Vicente defeated by the Rochela \\ paulista. The statement of São Paulo as head of the captaincy (1681-1766).
}

Amilcar Torrão FILHO*

\begin{abstract}
Resumo: A vila de São Vicente, primeira criada na América portuguesa, foi sede da capitania de mesmo nome e, apesar de muito "famigerada noutro tempo", como diz Frei Gaspar da Madre de Deus, acaba, no século XVIII, “tão desconhecida que nem o nome primitivo conserva para memória de sua antiga existência”. A primeira tentativa de mudança ocorreu em 1681, por obra do marquês de Cascais, donatário da capitania, que contou com a resistência da câmara de São Vicente. Após a restauração da capitania em 1765 o Morgado de Mateus, novo governador da capitania restaurada, transfere definitivamente o governo, a Sé, a junta de fazenda, a guarnição e a provedoria para São Paulo. A Marinha perde definitivamente o governo para o Sertão de serra acima. O objetivo deste artigo é compreender como a cidade de São Paulo adquiriu sua dominância em relação às demais vilas, chegando a renomear a própria capitania, colocando no esquecimento a anteriormente famigerada São Vicente.
\end{abstract}

Palavras-chave: São Paulo. São Vicente. Cidades e vilas. Capital. Cabeça de capitania.

\begin{abstract}
The village of Sao Vicente was the first "capital” of the Sao Vicente Captaincy. Despite being “once so famous” according to Frei Gaspar da Madre de Deus, Sao Vicente ends up in the eighteenth century, "so unknown not even its original name is kept toward the memory of its former existence”. The first attempt at change occurred in 1681 through the efforts of the Marquis de Cascais, Lord of the Captaincy, who did not have the support of the Council of Sao Vicente. After the captaincy was restored in 1765, Morgado of Mateus, the new governor, permanently transferred the government, the Se Cathedral, the treasury, the garrison and provisions to Sao Paulo. The Sea Realm lost to the government of the "Backwoods". The aim of this paper is to understand how the

\footnotetext{
* Professor Doutor - Departamento de História da Pontifícia Universidade Católica de São Paulo. Rua Monte Alegre, 984, Perdizes, São Paulo, CEP: 05014-901. E-mail: amilcartorrao@uol.com.br.
} 
A marinha destronada: ou a famigerada São Vicente derrotada pela Rochela paulista. A afirmação de São Paulo como cabeça de capitania (1681-1766).

city of Sao Paulo acquired its dominance over other villages, and had the Captaincy renamed, before casting the renowned Sao Vicente into oblivion.

Keywords: Sao Paulo. Sao Vicente. Cities and villages. Capital. Head of captaincy.

\section{A Construção de um Objeto}

Embora constituída como problema no século XIX, sendo objeto de uma nova ciência teórica e técnica - o Urbanismo -, a cidade tem sido relativamente negligenciada pela historiografia, não sendo por vezes mais do que um cenário para o desenrolar dos “fatos” históricos. A cidade colonial atraiu uma série de estudos - desde a publicação do clássico de Sérgio Buarque de Holanda, Raízes do Brasil, cujo capítulo “O ladrilhador e o semeador” era um ensaio comparativo entre as cidades coloniais de espanhóis e portugueses na América - muitas vezes marcados por uma visão enviesada e até mesmo anacrônica destes espaços urbanos tão peculiares, construídos em zonas de conquista e de contato, nos quais conceitos do urbanismo novecentista, como ordem e planejamento são transferidos para a análise dos espaços coloniais (TORRÃO FILHO, 2007) As cidades capitais tampouco têm tido uma maior atenção, com exceção daqueles casos de transferências das sedes de governo, muitas vezes resultado de mudanças políticas estruturais como a descolonização, ou o fim da União Soviética, por exemplo. Ou quando são criadas novas capitais a partir de planos ambiciosos e arrojados, como Brasília, que engaja projetos de modernização e regeneração nacionais cujo longo percurso vem desde a proposição de Nova Lisboa como capital da corte no exílio em 1808 (VIDAL, 2009). Capital desejada, sonhada e planejada, que pôde documentar, por meio de seu concurso, diversas concepções e desígnios propostos para a interiorização do Brasil dentro dos mais avançados princípios da arquitetura moderna (BRAGA, 2010).

Com relação às capitais nacionais, vem sendo destacado o papel importante que elas desempenham como fundamentos dos Estados modernos, nos quais a cidade deixa de ser um município livre e autônomo para tornar-se a sede da autoridade do Estado, dos órgãos de governo e da administração pública, das representações diplomáticas, localizadas geralmente no centro geográfico do país. Argan recorda que estas capitais deixam, a partir do século XVII, de serem espaços fechados em seus muros para tornarem-se “[...] um organismo aberto, um nó de vias de comunicação” (2004, p.71-72; GAMA, 1994). O centro geográfico é condição fundamental para a 
eficácia econômica de uma capital e as relações com as partes que lhe estão associadas, formando a sua região. Para Lepetit, o pensamento econômico urbano do Antigo Regime é dominado pelo modelo da cidade capital (LEPETIT, 2001). Elas constituem ainda espaços de inovação e transformações políticas e econômicas, dando mais eficiência às formas de produção, mesmo que por meio da improvisação, ainda que estejam inseridas num contexto conservador como o do Antigo Regime (RINGROSE, 1988). Segundo Rawat, a capital desempenha um papel vital na vida da nação, como "repositório do poder político e econômico", sendo a determinação de sua localização um problema central da formação dos Estados, tanto pré-modernos quanto modernos; assim, a construção e realocação das capitais é uma questão central para os projetos de construção das nações (RAWAT, 2005). Hancock considera que as capitais cristalizam o discurso nacional, vistas como símbolo do fato urbano e da própria nação; no caso de Londres e Paris, estas capitais de dois Estados que disputam a primazia do mundo no século XIX, são vistas como exemplo e contraexemplo das duas nações, constituem "[...] o suporte material, visível, de civilizações que se buscam opor termo a termo" (HANCOCK, 2003, p.9). Elas são as imagens que sintetizam as identidades nacionais de cada país e são mobilizadas para definir o caráter de cada povo nos guias e na literatura de viagem.

Se a análise específica das capitais atrai poucos estudos, são menos frequentes os trabalhos referentes às capitais coloniais, ou então às regionais ou provinciais, que não são centros de decisão e de administração dos Estados nacionais europeus (ZAGARRI, 1988), ou mesmo as cidades que perderam a sua condição de capitais, como a Lisboa dos Felipes ou a Barcelona da derrotada Catalunha (BOUZA, 1994; AMELANG, 2007). Menos ainda uma capital regional colonial como a São Paulo da passagem do século XVII para o XVIII, em uma capitania até certo ponto secundária como era o caso da antiga São Vicente, num espaço de conquista, pouco conhecido, no qual a centralidade não é geográfica, mas está relacionada à ocupação de espaços propícios à colonização, geralmente localizados em zonas litorâneas. Trataremos, aqui, deste lento processo no qual a pequena vila de São Paulo, primeiro núcleo urbano fundado no interior da América portuguesa, com exceção da efêmera Santo André, acabou por destronar não apenas uma, mas diversas outras capitais, afirmando a sua centralidade e dominância de boca do sertão e núcleo de conquista.

Musset observa que ao contrário dos espanhóis os portugueses utilizaram pouco a técnica de deslocamento de suas cidades, as cidades nômades de que trata, para se adaptar às realidades geográficas ou geopolíticas do mundo “brasileiro” (2002), com a impressionante exceção de Mazagão, transferida da África para a América (VIDAL, 2005). No caso de São Paulo de Piratininga, a elevação a vila e sua existência como núcleo urbano se deu justamente pela transferência da vila de João Ramalho, Santo André da Borda do Campo, para o local mais seguro 
A marinha destronada: ou a famigerada São Vicente derrotada pela Rochela paulista. A afirmação de São Paulo como cabeça de capitania (1681-1766).

dos campos de Piratininga. Nesta transferência, Cortesão vê a representação, na conquista do território por meio da ocupação urbana, da passagem “da posse superficial, - da Borda à posse plena, sem limitação, do Campo” (1955, p.229). O que este autor chamará, então, da constituição de São Paulo como capital geográfica do Brasil, com suas conexões, reais ou imaginárias, com o mundo hispânico, sobretudo platino. O outro deslocamento, mais lento, foi da marinha para a serra acima, quando os portugueses na América passaram a penetrar definitivamente o interior do continente, não mais apenas arranhando as costas como caranguejos, na expressão queixosa de Frei Vicente do Salvador. Uma capital nômade, que tem dificuldade em fixar-se, vila mal plantada numa sociedade movediça, com poucas razões para durar, diz Sérgio Buarque, mas que “despejando em periódicas pulsações as sobras de seu povo" (HOLANDA, 1966, p.66) espalhou-se “em novas comunidades que sucessivamente se vão formando ao largo do sertão” (Ibid., p.102). E com uma força que absorverá Santo André, que era a vila enquanto São Paulo era apenas uma aldeia, absorvendo seus moradores e seu nome, devido ao santo apóstolo da conversão do gentio, que passou do pequeno colégio para a vila, para a capitania e, recorda Washington Luís, para todo o território sertanejo. Se a capitania é de São Vicente, santo padroeiro dos navegadores, ou a esquecida Santo Amaro, outro navegador salvo por Nossa Senhora em uma ilha deserta, identificada ao Paraíso Terrestre, seus habitantes, nômades mas bastante terrestres, já se chamavam paulistas (LUÍS, 1980). Nômade também será o território submetido à centralidade desta vila centrípeta, do qual nunca serão claros nem seus nomes nem seus limites geográficos, nem mesmo a posse legítima, se castelhana ou portuguesa, se deste ou daquele donatário ou herdeiro, se senhorial ou da coroa. A definição de seu espaço, de suas fronteiras, de sua capitalidade, tudo isso será marcado por uma extrema mobilidade.

Tratando da constituição de São Paulo como capital, ou cabeça de capitania, algumas observações iniciais se fazem necessárias. Ao dizer Capitania de São Vicente, ou Capitania de São Paulo, estamos lidando com um inevitável grau de anacronismo, na medida em que este território, quase que automaticamente identificado ao atual Estado de São Paulo ou mesmo à capitania de São Paulo, tornada autônoma apenas em 1720, inicialmente foi formado por diversas capitanias hereditárias, aquilo que Sérgio Buarque de Holanda chamou de “as capitanias paulistas”, assim no plural (1966, p.55): as duas capitanias de São Vicente, pertencentes a Martim Afonso de Souza, intercaladas pela de Santo Amaro, mais a de Santana ao sul, o segundo quinhão das terras de Pero Lopes de Souza ${ }^{1}$. As terras doadas aos irmãos foram intercaladas na medida em que havia a possibilidade do encontro de minas de pedras preciosas. Dessa forma seria evitada uma possível injustiça de ficarem as desejadas minas incluídas numa única donataria, prejudicando algum de seus 
proprietários $^{2}$ (CALIXTO, 1924, p.106). Estas capitanias seriam objeto de uma longa disputa jurídica entre os descendentes dos donatários, que será fundamental na definição de São Paulo como cabeça de capitania, levando, também, à criação de uma nova, em 1624, quando a condessa de Vimieiro, descendente de Martim Afonso, perde a posse de parte de suas terras e cria a capitania de Nossa Senhora da Conceição de Itanhaém (Cf. CALIXTO, 1915).

Sendo assim, tratamos do território inicialmente dividido em cinco capitanias distintas, que formaram em diferentes momentos uma ou mais capitanias de diversos donatários, bem como de quatro capitais, três delas destronadas por São Paulo: São Vicente, a primeira vila da América portuguesa, criada em 1532, e primeira cabeça da capitania homônima; Santos, porto anexo a São Vicente, elevado à dignidade de vila em 1545, que em determinados momentos no século XVIII foi a sede de governadores sem a patente de capitães generais, dependentes do governo do Rio de Janeiro, e que por alguns meses recebeu o governador da recém-criada e restaurada capitania de São Paulo, D. Luís Antônio de Souza Botelho Mourão, o Morgado de Mateus, em 1765; Nossa Senhora da Conceição de Itanhaém, cabeça da pequena capitania da condessa de Vimieiro, tornada vila em 1561, que depois seria anexada à capitania de São Vicente; e São Paulo, aldeia jesuíta elevada a vila em 1560 com a transferência de Santo André, que passou por um lento processo de reconhecimento de sua centralidade e que culminaria no reconhecimento de sua capitalidade. A estas vilas, poderíamos ainda acrescentar uma quinta, a de Nossa Senhora do Carmo, futura cidade de Mariana, que a partir da criação da capitania de São Paulo e Minas do Ouro, em 1709, seria a cabeça de fato quando São Paulo se torna a cabeça de direito da nova capitania.

Neste processo, podemos identificar ainda três momentos distintos. O Primeiro ocorreu em 1681, quando o donatário Marquês de Cascais tentou elevar a vila de São Paulo à condição de cabeça de capitania, não tendo tido êxito por conta da reação da câmara de São Vicente, que se opôs a esta perda de dignidade, e à decisão contrária do governador geral do Brasil, o marquês das Minas. Outro momento importante data de 1709, quando é criada a capitania de São Paulo e Minas do Ouro, sendo São Paulo a sua sede nominal, embora os governadores vivessem nas Minas. E finalmente, em 1766, quando após a restauração de São Paulo, que havia sido extinta em 1748 e transformada em comarca do Rio de Janeiro, o governador Morgado de Mateus deixa a cidade de Santos e se instala definitivamente na serra acima, apesar dos protestos veementes dos camaristas do porto santista (TORRÃO FILHO, 2007).

Uma das características específicas das capitais coloniais é a sua constituição enquanto sede de um poder sempre delegado, não sendo a residência de um rei ou chefe de Estado, mas referenciada a outra capital que lhe tem precedência, em nosso caso Lisboa, o que poderia ser chamada uma “capital incompleta”. As cabeças de capitania seriam ainda mais “incompletas”, 
A marinha destronada: ou a famigerada São Vicente derrotada pela Rochela paulista. A afirmação de São Paulo como cabeça de capitania (1681-1766).

dependentes de uma capital local e outra externa, do outro lado do Atlântico. Nas capitanias que formariam São Vicente e, em seguida, São Paulo, até o século XVIII, a sua cabeça representa a autoridade e os direitos senhoriais de seu proprietário, o donatário, até o momento em que elas são adquiridas pela Coroa.

Como toda vila ou cidade, capitania representa a jurisdição administrativa e política portuguesa no ultramar e o controle de um vasto território que compreendia os lugares e as vilas sob a sua área de influência e um vasto sertão a ser explorado. Por outro lado, como descobriu o marquês de Cascais ao tentar elevar São Paulo à cabeça de sua capitania, esta autoridade também está limitada pelos direitos da Coroa em escolher ou manter as sedes de governo dos territórios dos donatários, decisão que, por sua vez, também deveria passar por Salvador, ou pelo Rio de Janeiro a pois, a partir de 1763 essas “capitais” que também tinham precedências em relação às sedes regionais da América portuguesa.

Outro grau de anacronismo com o qual devemos lidar ao tratar deste tema diz respeito ao termo capital. Embora aparentados, capital e cabeça não significam exatamente a mesma coisa. Bluteau define capital como algo principal, “o que é como cabeça, princípio, \& fonte, donde outras cousas se originam, ou em que outras cousas se encerram”(1712); pode ser, ainda o que é digno de morte, de pena capital, o que encerra uma vida ou uma condição de cidadão. Cabeça, que era como se denominavam as cidades principais dos reinos ou províncias, é definida inicialmente como “Cabeça do homem. O principal domicílio da alma, \& dos órgãos dos cinco sentidos”; também pode significar aquilo que é “primeiro no número, ou na dignidade. A cabeça do concelho”. Ou ainda: “Cabeça do Reino. A cidade principal de um Reino”. E por Cabeça do Império, “assento, \& Corte dos Visso-Reis”. (BLUTEAU, 1712).

Assim, cabeça é o termo que designa a cidade ou a vila principal do reino ou de uma província, uma vez que representa melhor a concepção da sociedade e do reino como corpo místico ${ }^{3}$ (BASTOS, 2006, 7-8), uma monarquia corporativa constituída por diversos membros que se integram em ordem e hierarquia, na qual a cabeça ordena e dá sentido ao corpo político, garantindo o bem comum da república e o equilíbrio da cidade com a ordem sagrada à qual ela deve corresponder ${ }^{4}$ (BASTOS, 2006; 2007). Este corpo místico confere homogeneidade, continuidade e perpetuidade à monarquia, que assim escapa à ação deletéria do tempo e da história, assegurando a permanência da comunidade, tanto espiritual como política.

A cabeça deve levar cada parte do corpo a corresponder à sua melhor conservação, garantindo o respeito às precedências e às hierarquias da sociedade correspondendo melhor à lógica da monarquia corporativa do que a ideia de uma capital de onde emana um poder a partir do centro 
que se irradia para as periferias de forma mais ou menos homogênea ${ }^{5}$. Por esta razão podemos entender a ação do Marquês de Cascais em sua tentativa frustrada de mudar a cabeça de sua donataria de São Vicente para São Paulo: a vila de Piratininga não seria uma sede do poder do marquês, que devia conviver com o equilíbrio das precedências dos poderes eclesiásticos, locais e régios, mas representaria a dignidade de seus direitos senhoriais ameaçados pela decisão da câmara vicentina, garantindo a justa conservação e decoro de seus direitos de legítimo donatário, seriamente contestados naquela ocasião.

Campbell chama a atenção para a falta de uma teorização sobre as cidades capitais, consideradas pouco mais do que centros administrativos, sem que se destaque seu caráter de teatros simbólicos da ideologia nacional, catalisadoras da economia do país, pontes entre a cultura local e a comunidade imaginada do Estado-Nação. Falta uma teorização sobre o papel da capital no período moderno, bem como uma definição do que há de diferente entre as capitais e as demais cidades (CAMPBELL, 2003). Como veremos no caso de São Vicente e São Paulo, essa ausência de teorização causa ainda mais problemas, pois se trata de capitais construídas num contexto colonial, sedes regionais de capitanias que pertencem a um vasto território de conquista, submetidas a um domínio senhorial, mas com funções de capitalidade definidas por decisão régia. Além disso, tratase de uma experiência histórica bastante diferente daquela definida por Campbell, de capitais inseridas num contexto nacional contemporâneo ou da construção dos Estados absolutistas.

São Vicente e São Paulo são as cabeças de poderes corporativos, partes de um organismo complexo, no qual todos os órgãos são indispensáveis, o que impossibilita um governo totalmente centralizado. “Tão monstruoso como um corpo que se reduzisse à cabeça”, afirma Hespanha, "seria uma sociedade em que todo o poder estivesse concentrado no soberano”. A função da cabeça, portanto, não é a de destruir a autonomia de cada membro do corpo social, mas a de, "por um lado, representar externamente a unidade do corpo, e, por outro, manter a harmonia entre todos os seus membros, atribuindo a cada um aquilo que lhe é próprio, garantindo a cada qual o seu estatuto" (HESPANHA, 1994, p.300).

Além de cabeça, parte mais importante de um corpo, a cidade capital das monarquias católicas é concebida como a esposa num matrimônio místico da cidade com seu rei, da monarquia com seu povo, do príncipe com o corpo místico da sociedade (BOUZA, 1994). Assim, uma capital destronada é, como recorda Bouza, uma “quase viúva” afastada de seu rei e esposo querido, como a Lisboa filipina, abandonada pelo "sertão" castelhano no período da união dinástica (1994). A capital destronada aparece como uma cabeça que perde seu corpo, da mesma forma que uma cidade dominante funciona como uma cabeça que busca sua união mística com o corpo que de fato representa. 
A marinha destronada: ou a famigerada São Vicente derrotada pela Rochela paulista. A afirmação de São Paulo como cabeça de capitania (1681-1766).

Uma capital colonial é também uma esposa em núpcias, contraídas em uma união mística que une o espaço da conquista sobre o gentio à monarquia apostólica de Portugal, juntando as partes desconexas do espaço imperial num corpo ordenado e harmônico. São Vicente é nossa rainha destronada, esposa abandonada e trocada pela jovem noiva do planalto, ataviada com os brilhos das minas do sertão, num novo contrato matrimonial, contraindo uma nova harmonia e equilíbrio. Portanto, diferentemente das capitais contemporâneas, as cabeças do Antigo Regime não possuem este caráter de centros da administração, da burocracia e dos negócios dos governos nacionais, elas próprias são resultantes da formação dos Estados-Nação (CAMPBELL, 2003); elas não concentram os poderes de decisão de um Estado, são antes espaços nos quais convergem os poderes, onde a administração política, eclesiástica, das justiças, dos negócios poderia estar repartida por diversas vilas. E no caso colonial, funcionam como polos de ocupação e construção de um território europeu e cristão na América, tendo que lidar, e muitas vezes competir, com as autonomias das demais vilas e cidades, com a diversidade de jurisdições e poderes. Ainda que sejam, como observa Campbell, para as atuais capitais, cidades que são diferentes das demais, com uma experiência histórica própria.

\section{Fronteiras Movediças}

A divisão intercalada das capitanias entre os irmãos Martim Afonso e Pero Lopes de Souza provocou uma confusão de seus limites e uma indefinição, para seus descendentes, das exatas propriedades, gerando um longo e complicado processo judicial ${ }^{6}$. O litígio começou quando a sucessora da Capitania de Santo Amaro, D. Isabel de Lima de Souza Miranda, que não tinha filhos, deixou em testamento a seu primo Lopo de Souza, donatário de São Vicente, a sucessão de Santo Amaro, juntando as duas capitanias. O conde de Monsanto, também neto de Martim Afonso pela rama materna, reivindicou, por sua vez, a Capitania de Santo Amaro. Morto o seu primo Lopo de Souza em 1610, este deixa como herdeira a sua irmã, condessa de Vimieiro. A sentença favorável ao conde é dada em 1615, recebendo a posse da capitania de Pero Lopes de Souza. Entretanto, a condessa de Vimeiro não chegou a pedir a confirmação de sua Capitania de São Vicente, que estava fora da disputa, e acaba perdida também para o conde de Monsanto, demonstrando a forma como essas capitanias foram se confundindo com o tempo e suas denominações mudadas e intercambiadas.

A demarcação das capitanias dos dois primos é feita em 1623: o conde fica com a assim chamada, a partir de agora, capitania de São Vicente, desaparecendo a denominação de Santo 
Amaro, incluídas as vilas de São Vicente, São Paulo e Santa Ana de Moji. A condessa nomeia as terras que lhe couberam como capitania de Itanhaém, com sede na vila homônima. A contenda não acabaria aqui, o conde da Ilha do Príncipe, herdeiro das terras de Itanhaém, reivindica aquelas que estavam em poder dos Monsanto, que lhes são restituídas em 1679, até que o marquês de Cascais, herdeiro do conde de Monsanto, retoma a sua propriedade em 1692.

Essa disputa teria um desfecho provisório em 1711, quando as capitanias são vendidas pelo marquês de Cascais à Coroa por 40.000 cruzados, em outra negociação confusa, já que realmente estava sendo vendida a capitania de Santo Amaro e não a de São Vicente, como estavam sendo chamadas as terras do marquês de Cascais (Cf. SILVA, 2009). O impasse se estenderia durante todo o século XVIII, quando a casa de Vimeiro mobiliza personagens como o genealogista Pedro Taques, os governadores Morgado de Mateus e Martim Lopes Lobo de Saldanha ou o ouvidor Marcelino Pereira Cleto, na tentativa de provar seus direitos sobre a Capitania de São Vicente, transformada em São Paulo, caso solucionado apenas em 1825, no Tratado de Reconhecimento da Independência do Brasil, quando os Vimieiro são finalmente indenizados (VIANNA, 1969).

Com a posse dada pela câmara de São Vicente ao conde da Ilha do Príncipe em 1679, começa a disputa pela precedência na cabeça da nova capitania de São Vicente que estava se formando. O reconhecimento dado ao conde da Ilha permitirá com que o marquês de Cascais, temporariamente alijado de suas terras, passe uma provisão dando à vila de São Paulo, que se havia negado a reconhecer a posse de seu adversário, o título de cabeça de sua capitania em 22 de março de 1681. Em carta à câmara de sua vila fiel e preferida, registrada pelos camaristas em 16 de julho de 1682, o marquês de Cascais reconhece o zelo com o qual os seus moradores defenderam a sua jurisdição contra a decisão intempestiva, em sua visão, dos camaristas de São Vicente. Por isso justifica a cessão da primazia de toda a sua capitania a São Paulo, a quem toca a partir de agora “zelar hoje os meus particulares mais do que nunca maiormente amando eu a esse povo mais do que a todos”. O que esperava o marquês de sua nova cabeça era a resistência a qualquer agravo contra os seus direitos que a câmara de São Vicente lhe pudesse fazer, por ressentimento de havê-los "feito súditos”, dependentes da precedência então adquirida pela vila de São Paulo .

A câmara da nova cabeça comunica ao capitão-mor da capitania, ao ouvidor geral, às demais câmaras e ao governador do Rio de Janeiro a decisão de seu senhor. Também comunica aos habitantes da vila, em 27 de abril de 1683, chamando alguns homens bons para que fossem a praças e lugares públicos, com o capitão-mor, dar notícia da patente com a qual o marquês havia feito mercê à vila, tornando-a cabeça de sua capitania com todos os privilégios e dignidades que até então havia gozado a vila de São Vicente, clamando para que se apresentasse qualquer um que tivesse alguma provisão em contrário, para que então se fizesse o auto de posse ${ }^{8}$. A câmara 
A marinha destronada: ou a famigerada São Vicente derrotada pela Rochela paulista. A afirmação de São Paulo como cabeça de capitania (1681-1766).

vicentina também é comunicada, com muito cuidado, em 4 de outubro de 1684, invocando as razões da câmara de São Paulo para considerar-se nova cabeça de capitania: “inda assim”, diz a carta dos camaristas, "não ignoramos que vossas mercês as suas as tenham com a mesma opinião.”

Pedem, então, que os oficias enviem a São Paulo alguma provisão ou alvará com os quais os reis tenham feito mercê de primazia a São Vicente, caso no qual "não duvidaremos obediência de leais vassalos e lograremos o favor do maior cessando a do menor que é a do senhor Marquês por onde essa câmara de presente logra a primazia.”’9 (CARTA..., 1684, p.416)A resposta vem em 21 de janeiro de 1685, na qual os oficias de São Vicente recordam que "bem se sabe que o inimigo queimou esta vila e nessa ocasião arderiam os papéis” com os quais se poderia provar a mercê real feita à vila, que se sobreporia à determinação do donatário, afirmando aparentemente respeito e submissão à decisão do marquês ${ }^{10}$. Segundo Benedicto Calixto a câmara de São Vicente possuía cópias de diversas provisões, cartas régias e alvarás que provariam a primazia da vila, tendo procedido “astuciosamente”, fingindo concordar com os vereadores de São Paulo, ao mesmo tempo em que apelava para a Relação da Bahia e para o Governador, pedindo revogação do ato do marquês (CALIXTO, 1924).

O marquês das Minas, governador geral da Bahia, resolve a questão favoravelmente a São Vicente, comunicando a sua decisão à câmara de São Paulo, em 6 de setembro de 1684. Nesse ínterim, a câmara de São Paulo faz uso de suas prerrogativas de cabeça, não dando posse a Pedro Taques de Almeida como capitão-mor da capitania, por ter sido ele empossado na câmara vicentina. O governador geral afirma aos camaristas de São Paulo que não tinham razão em não reconhecer o capitão-mor, uma vez que São Vicente era, por mercê particular do rei D. João III feita ao primeiro povoador, Martim Afonso de Souza, aquela que tinha a primazia da capitania. Portanto, uma provisão do donatário “não tem poder nem jurisdição” para definir uma nova cabeça, “tocando só a Sua Majestade esta divisão”, devendo os vereadores de São Paulo, “de razão e justiça”, ceder de sua opinião, “ficando como sempre a capitania de São Vicente a cabeça como sempre se observou”, devendo em caso contrário recorrer a Sua Majestade, exigindo da edilidade que mantenha, com prudência, “toda a quietação e sossego dessa capitania”11(Carta...).

Respondendo à câmara de São Vicente, o governador geral reitera o seu apoio à demanda dos camaristas, afirmando que não era justo perverter a cabeça da capitania, uma vez que era uma posse tão antiga, apenas com uma provisão do donatário, sem ordem expressa de Sua Majestade ${ }^{12}$. Ao capitão-mor, o governador afirma categoricamente que o requerimento do marquês de Cascais não tinha “propósito nem fundamento algum”, e que se continuasse com outros semelhantes “mandá-lo-ei vir aqui preso, e então saberá se o Governo Geral tem poder ou não para prover as 
vacâncias”. Reafirma que apenas o rei tinha o poder de instituir a vila de São Paulo como cabeça em lugar de Santos (confundida com a vila de São Vicente ou então um indicativo de que Santos já começava a sobrepujar a sua vizinha na marinha) $)^{13}$.

A câmara piratiningana resiste o quanto pode a dar posse a Pedro Taques, o que significaria capitular definitivamente e desistir de suas pretensões de firmar-se como cabeça da capitania. O capitão-mor argumenta, em uma petição, que não havia sido reconhecido pela vila de São Paulo por ter tomado posse naquela que era cabeça dessa capitania, "na forma que o fizeram de seu princípio até o presente os mais capitães-mores”. A posse em São Vicente se justifica por sua muita antiguidade como sede, o que já tinha sido afirmado pelo marquês das Minas, além de ser uma mercê régia. Pedro Taques acusa a câmara de São Paulo de "cavilosamente formarem culpas a ele suplicante”, incriminando-o para não reconhecer a ordem do governador. Como não era permitido fazer nenhum procedimento contra quem tivesse posto na milícia ou na justiça, enquanto este estivesse exercitando a administração, recorda o capitão-mor, a insistência da câmara em processálo funcionava como uma manobra que não reconhecia a sua posse realizada em São Vicente, afirmando, assim, a precedência de São Paulo ${ }^{14}$. Neste primeiro de março de 1685, quando Pedro Taques é reconhecido pela câmara paulistana, acaba a efêmera primazia dada pelo marquês de Cascais a São Paulo. A tentativa do donatário em premiar a lealdade de São Paulo esbarrou nas prerrogativas do rei em definir as cabeças de capitania, bem como na tradição e na antiguidade das primazias de São Vicente ${ }^{15}$.

\section{A Rochela do Sul}

Além da lealdade demonstrada ao donatário, a vila de São Paulo, conhecida como a Rochela do Sul, dava mostras da consciência de sua independência, quase solitária que vivia nas terras de serra acima, na boca do sertão, enfrentando os seus perigos e descobrindo as suas riquezas. Em 10 de janeiro de 1683 ocorre um levantamento na vila, que obrigou aos vereadores fazerem uma vereação “extraordinária”, aos gritos de “viva o povo e morte ao mau governo”, com ameaças de morte contra os oficiais da câmara, que não queriam proceder à vereação por falta do procurador do conselho. Tudo porque não desejavam que viessem a essa vila nem ouvidores gerais nem corregedores da comarca, invocando um suposto privilégio dado pelo rei ao donatário ${ }^{16}$.

Crendo-se cabeça da capitania, os revoltosos exigiam as precedências e direitos devidos à sua dignidade, e a independência em relação a uma correição que não condizia com os privilégios que acreditavam possuir, mas que não pôde ser evitada. Em vereação de 16 de abril de 1700, irá debater a câmara de vereadores, “em nome deste povo e das mais Vilas anexas”, outros privilégios e 
A marinha destronada: ou a famigerada São Vicente derrotada pela Rochela paulista. A afirmação de São Paulo como cabeça de capitania (1681-1766).

direitos, como a posse de terras das minas de Cataguases. Assim, tanto campos como matos lavradios que “de direito pertencia aos paulistas" por terem sido eles os "que conquistaram as ditas terras e são os descobridores das minas do ouro que presentemente se lavram o que é notório e patente”, tudo feito, obviamente, “a custo de suas vidas e fazendas sem dispêndio da fazenda Real”. Portanto, seria uma grande injustiça, argumentavam os vereadores, que se concedesse aos moradores do Rio de Janeiro direitos sobre estas terras já que nunca tiveram parte em sua conquista ou descobrimento ${ }^{17}$.

Os levantes eram comuns em São Paulo, e a questão das minas de Cataguases, assim como as desordens pelos monopólios da carne ou do abastecimento de sal estão, para Romeiro, na origem do conflito dos Emboabas. Tensões que opuseram os paulistas aos chamados emboabas, os forasteiros, mas também opunham a vila aos mercadores de Santos, tidos por açambarcadores e atravessadores (ROMEIRO, 2008). Conforme esta autora, a guerra dos Emboabas que se desenrola entre 1708 e 1709 está marcada pela legenda negra paulista, que representava São Paulo como um bastião incrustado no sertão, inexpugnável à autoridade régia, livre da ingerência das autoridades, couto de fugitivos e bandidos.

Esta legenda negra estaria marcada pela imagem de autonomia e independência política dos homens de São Paulo, que não se considerariam vassalos do rei, recusando-lhe obediência e submissão, vivendo nessa Rochela inexpugnável. Os paulistas não se veriam como vassalos do rei, mas como arrendatários de suas terras na América (ROMEIRO, 2008). A lealdade “paulista” era dependente, assim, da sua devida recompensa, resultado de um imaginário político que advinha de um aprendizado de negociação das diversas vezes em que foram acionados para prestar serviços ao rei. Essa negociação por vezes acintosa era vista como uma fidelidade suspeitosa, incerta e ambígua (ROMEIRO, 2008).

Essa visão contratualista da lealdade pode explicar a adesão da vila de São Paulo à causa do marquês de Cascais, contrariando a cabeça da capitania que havia acatado a decisão favorável ao conde da Ilha do Príncipe. Essa lealdade é trocada pela dignidade de tornar-se a cabeça da capitania, num momento em que esta precedência poderia auxiliar a vila a legitimar as suas pretensões com relação às descobertas das minas, que teria como resultado o conflito emboaba.

Estas descobertas e conflitos tiveram como resultado a criação da capitania de São Paulo e Minas do Ouro, por carta régia de 9 de novembro de 1709, com a nomeação de Antônio de Albuquerque Coelho de Carvalho para o cargo de governador. Esta nova unidade administrativa tinha como função a melhor gestão das minas descobertas, a resolução dos conflitos por sua posse, a fundação de povoações para que as pessoas “vivam reguladas, em a subordinação da Justiça”, além 
obviamente de conter os descaminhos do ouro e garantir a arrecadação do quinto. A carta régia estabelece ainda a nomeação igualitária para os cargos da república e governo das povoações de paulistas e reinóis, não fazendo diferença entre eles ${ }^{18}$.

Oficialmente, a partir de agora a vila de São Paulo se torna a cabeça da nova capitania; o governador informa ao rei João V que estava a caminho das Minas, passando primeiramente em São Paulo, onde lhe parecia conveniente tomar posse do governo para "persuadir aqueles povos a sua obrigação”, fazendo assim com que vivessem em harmonia com os forasteiros das minas, conforme os desejos de Sua Majestade. Ele comunica também à câmara da vila a decisão régia de torná-la cabeça da nova capitania $^{19}$. Entretanto, logo em seguida passará para as zonas de mineração, onde efetivamente viveria e governaria distante de sua sede, passando os governadores a maior parte do tempo na vila de Nossa Senhora do Carmo, erigida em 1711, futura cidade de Mariana ${ }^{20}$. Na zona de fronteira, pouco ocupada, a centralidade de São Paulo já tinha sido reconhecida, mas a necessidade de povoar e levar as justiças ao interior, para garantir a quietação dos povos e a conveniente arrecadação, com temor e respeito à coroa, levava os governantes às zonas turbulentas da mineração.

Tornar São Paulo cabeça de capitania apenas nominal funcionava para conciliar os paulistas, ao mesmo tempo em que eram afastados da administração das minas, já que a verdadeira cabeça se encontrava onde era mais necessária segundo o governador. Por isso as instruções régias deixavam ao seu critério a escolha de sua residência, que poderia ser em "qualquer destas partes que vos parecer mais conveniente ao meu serviço” ${ }^{21}$ Em carta à câmara datada de 16 de dezembro de 1711, o Rei informa aos vereadores, que lhe haviam escrito questionando-o sobre o domicílio do governador, que ele, assim como seus sucessores, deverão "assistir nessa vila como cabeça de comarca ou nas minas”, sendo porém São Paulo “a cabeça principal dessa capitania”, não significando que eles não possam ir a todas as terras e partes "que a necessidade o pedir, e for mais do meu serviço”22(1917, p.73). A posse em São Paulo indica o reconhecimento não apenas da importância crescente da vila, mas da necessidade de pacificação dos vassalos rebeldes, trazendo a nova capitania ${ }^{23}$ “à órbita do Império, infundindo neles os valores políticos do Antigo Regime” (ROMEIRO, 2008, p.308).

Por outro lado, o porto de Santos será afastado do governo do planalto, não pelos conflitos entre paulistas e santistas, mas para manter a jurisdição das minas cada vez mais dependentes do Rio de Janeiro. O governador argumenta sobre a conveniência de manter o porto de Santos atrelado ao governo da nova capitania, como um porto seguro para o abastecimento das povoações e vilas de serra acima, além de ter sido parte da antiga capitania de São Vicente, então já denominada São Paulo $^{24}$. Os oficiais da câmara da vila de Santos também solicitam ao rei, em 15 de setembro de 
A marinha destronada: ou a famigerada São Vicente derrotada pela Rochela paulista. A afirmação de São Paulo como cabeça de capitania (1681-1766).

1710, que seu porto ficasse subordinado à capitania de São Paulo e Minas do Ouro, com receio da distância em relação ao Rio de Janeiro ${ }^{25}$.

Apesar do apelo do governador e dos vereadores santistas, o rei decide pela subordinação de Santos ao governo do Rio de Janeiro, sendo mais conveniente que não ficasse nenhum porto de mar unido a São Paulo, para que não houvesse comunicação das minas com nenhum porto que não fosse o do Rio, e apenas pelo caminho novo ${ }^{26}$. Se a vila piratiningana recebera o reconhecimento de sua função como ponta de lança dos descobrimentos do ouro e sua importância como entroncamento de caminhos, o Rio de Janeiro aparece como um centro mais fiel à defesa dos interesses fiscais da coroa, antecipando uma decisão que seria tomada apenas em 1763, de elevação da cidade à cabeça da monarquia na América (Cf. BICALHO, 2006).

Os protestos do governador das dificuldades de acesso dos paulistas às minas pelo caminho novo, muito distante, bem como as dificuldades para a defesa e abastecimento do planalto não serviram para demover Sua Majestade da decisão de desvincular Santos da serra acima. Aqui percebemos também como a vila de São Vicente perdeu sua antiga importância e privilégios não apenas para São Paulo, mas também para o porto de Santos, que passa em alguns documentos a dar nome a essa curiosa e movediça capitania, que se movia tanto no espaço, de fronteiras incertas, quanto nas suas denominações.

Já antes da criação da nova capitania, a capitalidade de São Vicente estava sendo colocada à prova. Os oficiais da câmara vicentina se queixam ao rei em agosto de 1703 de que o pagamento do ordenado do ouvidor geral deveria ser pago nesta vila e não em São Paulo, ao que o rei contesta que, ainda que seja São Vicente cabeça da capitania, não era de comarca, devendo se fazer o pagamento em São Paulo, onde “assiste o ouvidor Geral na qual se lhe deve fazer o pagamento de seu ordenado"27 (ORDENS REAIS No 49, 1704). Aqui temos um detalhe importante, pois o rei havia feito de São Paulo cabeça de comarca em 1704, o que lhe acrescentava certas dignidades, repartindo a justiça pelas suas vilas anexas.

A comarca, como explica Bluteau, é a marca, ou limite de um território, o espaço de terra “em que se encerra a jurisdição de um corregedor”, vivendo debaixo “da mesma vara da justiça”. Vem a ser ainda multidão de gente vivendo debaixo da mesma vara de justiça. Ou um certo número de vilas cuja jurisdição tem os ministros da cabeça dela, a qual é cidade ou “vila grande e notável”, na qual reside o corregedor e provedor de toda a comarca. São Paulo está à frente da comarca neste momento, mas sem ter ainda retirado os direitos de cabeça de São Vicente, que vê novamente suas prerrogativas divididas com a vila de serra acima. 
Em 1713, o rei decide que a então cidade de São Paulo deveria, sendo cabeça de comarca, e oficialmente também de capitania, fazer uma casa de cadeia segura, de pedra e cal ${ }^{28}$. Em 1724, São Paulo solicita às vilas da capitania que enviem seus criminosos para a cidade para que fossem presos ali, onde havia menos possibilidades de fuga ${ }^{29}$.

Para a constituição da nova capitania foi necessária a compra da antiga donataria de São Vicente ao marquês de Cascais, passando à coroa a posse das terras da capitania de Santos e São Vicente, realizada em 1711, depois de ter o marquês tentado vendê-la ao potentado paulista José de Góis de Morais. A antiga São Vicente, ou o que ela se tornara depois de tantas disputas, anexações e desmembramentos, havia se tornado a principal capitania para a coroa, por isso a necessidade que ela fosse retirada de sua condição senhorial. Compreendendo "muitas vilas de tão grande jurisdição” não cabia mais que ela fosse uma propriedade particular, passando a ser patrimônio real $^{30}$. Nesta compra, acabaram por se confundir novamente as capitanias de São Vicente, Santo Amaro, que seria originalmente a propriedade do marquês de Cascais, e a pequena Itanhaém, sem contar o desmembramento da capitania do Rio de Janeiro, que originalmente fazia parte das terras doadas a Martim Afonso de Souza; a anexação de Itanhaém só seria desfeita com indenização aos herdeiros no reinado de Maria I.

Nem mesmo a coroa sabia ao certo os limites das capitanias. Em 1730 ela ainda procurava saber se as capitanias de São Paulo de Piratininga, São Vicente e Nossa Senhora da Conceição de Itanhaém “eram uma só capitania debaixo de diferentes nomes, ou são diversas capitanias que se formaram das cem léguas concedidas ao primeiro donatário”31(ARQUIVO HISTÓRICO ULTRAMARINO).

No processo de arregimentação dos paulistas, ao mesmo tempo em que são afastados dos negócios das minas, a vila é elevada à categoria de cidade em 1711, juntamente com a compra da capitania, uma compensação por ter se tornado uma cabeça sem governo. Seguramente, na avaliação de parecer do Conselho Ultramarino em 12 de fevereiro de 1711, era uma forma de satisfazer e contentar os paulistas que desejavam essa honraria bem como a criação de um bispado, o que dependeria da avaliação do número de famílias que pudesse fazer frente às côngruas dos Bispos $^{32}$.

A elevação à categoria de cidade atende a um pedido da câmara de São Paulo, enquanto a criação do bispado se efetivaria apenas em $1745^{33}$. Essa distinção representa o reconhecimento da coroa à nova dimensão de São Paulo “na geografia da América portuguesa” (ROMEIRO, 2008, p.309), o reconhecimento de sua capitalidade que vinha sendo exercida de fato, ainda que não totalmente reconhecida de direito. 
A marinha destronada: ou a famigerada São Vicente derrotada pela Rochela paulista. A afirmação de São Paulo como cabeça de capitania (1681-1766).

\section{Uma Noiva Engalanada}

Essa separação teria outro desdobramento, na criação da nova capitania de São Paulo, separada das Minas por alvará de 2 de dezembro de 1720, instituindo dois governos separados para as Minas e São Paulo, que recebe de volta as suas vilas da marinha de Parati, Ubatuba e ilha de São Sebastião ${ }^{34}$. As distâncias entre São Paulo e as Minas e a falta de assistência e de acesso às justiças fizeram com que fosse decidida a separação (ELLIS, 1975). Uma questão, aliás, importante na definição das novas capitais americanas no século XVIII, a sua proximidade geográfica funcionaria como uma garantia de representatividade dos povos e acesso à justiça (ZAGARRI, 1988).

Dois anos depois, uma carta régia devolve o porto de Santos a São Paulo no governo de Rodrigo César de Menezes, que foi o primeiro governador a habitar a capital piratiningana em 1721, deixando o porto de estar sujeito ao governo do Rio de Janeiro ${ }^{35}$. Com a criação da capitania separada das Minas, já não havia mais a necessidade de separar a serra de seu porto, evitando o descaminho do ouro. Ao mesmo tempo São Paulo ainda divide jurisdições com a marinha, não mais com São Vicente, caída em esquecimento, mas com Santos.

O novo governador de São Paulo, Rodrigo César de Menezes tenta transferir a arrematação de contratos reais dos dízimos para a cabeça de sua capitania. Após uma queixa do provedor da fazenda real de Santos, o rei adverte ao governador, em carta 11 de agosto de 1722, para que a respeito do lugar onde se arrematava esse contrato e sobre as propinas dos governadores "se não inove cousa alguma”, sobretudo sem ter havido “ordem minha para essa alteração e mudança de lugar”36. São Paulo ainda deverá disputar as precedências com Santos até a segunda metade do século XVIII, quando então, ressuscitada a capitania, haverá a sua assunção definitiva à capitalidade.

A batalha pela centralidade teria um novo revés, com a extinção do cargo de governador em São Paulo, em 1748, cuja capitania é transformada em comarca do Rio de Janeiro e seus assuntos militares atribuídos a um governador da praça de Santos sem patente de capitão general e sob a jurisdição do governador do Rio de Janeiro, sendo também desmembradas e criadas as capitanias de Goiás e Mato Grosso. A sua extinção teria se dado pela necessidade de concentrar esforços e assistência no extremo oeste, produtor de ouro, e a impossibilidade dessa assistência vir da cidade de São Paulo, cabeça muito distante do resto dos membros do corpo americano (BELLOTTO, 1979; Cf. DERNTL, 2010).

Esta situação, vista pelos contemporâneos e por muitos historiadores como período de decadência de São Paulo, perdurou até a sua restauração em 1764, depois de requerimento da 
câmara de Piratininga. Mais uma vez, os paulistas utilizam como argumento para receber uma mercê, a de restauração da capitania neste caso, em carta ao rei, de agosto de 1752, a conquista de vastas nações de gentio que vivia em “dilatados, e incultos sertões das Minas Gerais, Cuiabá e Goiases”, nos quais se encontraram as pedras e metais preciosos, "à custa de suas vidas, e fazendas”. Como “remuneração destes serviços”, utilizando o tom contratualista que Romeiro identifica no discurso político de São Paulo, os vereadores pedem que enviasse o rei, um capitão general que os trouxesse "polícia e lhes fizesse administrar justiça”, uma vez que tinham sido espoliados daquelas minas “de que foram progenitores”, merecendo, portanto, a real atenção a suas necessidades. Depois de tantas conquistas, estavam agora sujeitos a buscar justiça no Rio de Janeiro, sob riscos de vida na travessia marítima, por isso solicitavam um general que vivesse na cidade, uma capital esquecida que clamava por um bom governo ${ }^{37}$, uma esposa que buscava 0 reconhecimento de seus direitos matrimoniais.

Sem conseguir sensibilizar Sua Majestade, os oficiais da câmara escrevem novamente ao rei em 12 de fevereiro de 1763. Aqui a anexação de São Paulo ao governo do Rio de Janeiro aparece como um engodo de que padeceu o próprio rei, enganado por informações de quem "mais atendia a ampliar os limites da sua jurisdição do que o real serviço de Vossa Majestade” (CARTA... 1763). Argumentam que a presença de um general poderia aumentar as descobertas de preciosidades que enriqueceriam a coroa, como nos tempos de Rodrigo César de Menezes. Rebater os castelhanos que facilmente passavam pelo sertão em direção às terras portuguesas também é argumento utilizado para justificar o envio de um governador, o que parece ter pesado na decisão da restauração feita em seguida. E, finalmente, alegam que a existência de generais em Cuiabá e Goiás deveria dar mais razão à sua súplica, uma vez que havendo governo próprio nessas capitanias que em outro tempo foram sujeitas a São Paulo, “não se deve negar à cabeça a honra que se concede aos membros”’38.

A existência de governo próprio em territórios outrora submetidos a São Paulo, quando este não o possuía, criava na visão dos paulistas, um desequilíbrio no corpo político da monarquia, dando aos membros prerrogativas negadas à cabeça, daí a legitimidade de suas pretensões pelo envio de um governador que reafirmasse esse equilíbrio perdido

O conde da Cunha, vice-rei do Brasil entre 1763 e 1767, também escreve ao rei em 12 de agosto de 1764, afirmando estar reduzida a capitania a um estado lastimável, sendo impossível governar as capitanias de São Paulo e Rio de Janeiro conjuntamente, pelas distâncias e por serem os habitantes de São Paulo “excessivamente inquietos e revoltosos, em território abundante de minas de ouro e nas vizinhanças dos castelhanos”39.

Em carta ao Secretário de Negócios da Marinha e Ultramar, Francisco Xavier de Mendonça Furtado o conde da Cunha afirma que por conta do “miserável estado a que se achava reduzida”, 
A marinha destronada: ou a famigerada São Vicente derrotada pela Rochela paulista. A afirmação de São Paulo como cabeça de capitania (1681-1766).

pela falta de governo e pela proximidade da cidade de São Paulo com o novo descoberto de São João de Jacuri, Sua Majestade decidira nomear a D. Luís Antônio de Souza Botelho Mourão, o Morgado de Mateus, para governador e capitão-general de São Paulo. Entre suas atribuições estava a definição dos limites com as Minas e Goiás, além de sua recuperação, dado o miserável estado em que se encontrava ${ }^{40}$.

Interesses diversos orientaram a restauração de São Paulo: a mudança do eixo político para o sudeste da colônia, com a transferência da capital para o Rio de Janeiro em 1763, o desejo da Coroa em policiar o contrabando das minas, os interesses dos mercadores paulistas em ter governo próximo, que atentasse aos seus interesses e as questões de fronteira com os castelhanos no sul, que por mais de uma vez quase chegaram à declaração de guerra entre os dois reinos ibéricos.

\section{O Milagre da Onipotência}

Tudo isto e muito mais me é ainda necessário para restabelecer este estado de letargo, em que se achava [a capitania de São Paulo]; o criá-lo de novo seria muito menos, porque a criação das cousas é obra da Natureza; o ressuscitá-las milagre da Onipotência. Para Deus criar o Mundo bastou-lhe uma palavra, e para o restaurar desceu dos Céus, gastou trinta anos, e custou-lhe a vida.

Morgado de Mateus. ${ }^{41}$

Ao chegar à restaurada capitania que iria governar, o Morgado de Mateus permanece cerca de nove meses em Santos onde, segundo ele mesmo, iniciou o seu governo "pelo assim pedirem as urgências do Rio de Janeiro”. Passou, em seguida à cidade de São Paulo onde ratificou a sua posse, como capital que era, em 7 de abril de 1766, dia de Nossa Senhora dos Prazeres, santa da devoção de sua casa em Portugal ${ }^{42}$. Nesta mudança, teve o governador que tratar com a resistência de Santos para transferir-se definitivamente para São Paulo. Esteve em Santos desde sua chegada em 23 de julho de 1765 até 2 de abril de 1766, demorou-se nesta vila para reorganizar a Provedoria e informar-se do estado da capitania que iria governar. No entanto desejava que a posse como governador se desse apenas em São Paulo, “para não ‘escandalizar’ os habitantes”, e também porque "eram as Câmaras que empossavam um Capitão General, quando lhe faltasse antecessor” (BELLOTTO, p. 88; Cf. TORRÃO FILHO, 2007, p. 202).

Os oficiais da câmara de Santos enviam uma representação ao rei para demonstrar a inconveniência da sua partida para São Paulo. Com a extinção da capitania ela passa a ser governada, como apontamos anteriormente, por um governador sem patente de capitão-general e 
subordinado ao governador do Rio de Janeiro. Com isso, a câmara santista procura manter o governador na marinha, o que seria uma forma de sobrepor-se à cidade de São Paulo.

Em representação de 6 de agosto de 1766, argumentam os oficiais que nos nove meses em que esteve o capitão-general e o governo em Santos, “se via a dita Praça e suas Fortalezas totalmente fortificadas com o preciso $\mathrm{n}^{\circ}$. de gente que carecia para sua defensa”, levando o povo da vila a julga-la segura "por terem nela a principal cabeça que a regesse em todas as ocasiões que fossem necessárias” ${ }^{\star 3}$. No entanto, com a saída do governador ficou a mesma praça destituída não só do governo como “da gente de guerra que saiu da mesma para S. Paulo com o dito governador e para outros lugares”.

Representou-se ao governador a conveniência de residir o governo em Santos, mas sem sucesso. Assim, os oficiais decidiram escrever ao rei, apontando as conveniências do governo se localizar nesta vila, como o fato de ser praça aberta em porto de mar, onde sempre residiram todos os generais, e não em São Paulo, “onde se não carece de sua assistência”, e ainda por estar Santos sob o comando de um simples capitão-mor de Infantaria, com limitado número de trinta soldados, por se acharem uma companhia inteira em Paranaguá e outra em São Paulo. Para terem mais tropas e maior segurança, se oferecem para pagar as tropas que se estabelecessem na vila. Queixam-se, ainda, de ter transferido o governador a Provedoria de Fazenda Real, levando consigo contratos e estancos com notório prejuízo para Santos, apenas “por querer residir em S. Paulo”.

Tentando sensibilizar o rei, os camaristas da marinha afirmam que se Sua Majestade soubesse onde ficava a cidade de São Paulo “e a distância que vai desta Praça, não consentiria que o Governador Cap. General ali residisse, sem utilidade alguma devendo estar nesta Praça onde se faz indispensável a sua assistência”.

O provedor da Fazenda, José Honório de Valadares e Aboim, também demonstra sua insatisfação com a decisão régia, cumprida pelo governador, de transferir o cofre e a provedoria para a cidade de São Paulo. Diz ao capitão-general que se deveria esperar uma decisão do rei, depois de sua representação, porquanto não será “da sua Real Intenção dispor cousa que prejudique à Sua Real Fazenda, pois não pode estar o cofre tão distante da Praça principal, e porto do Mar aonde precisamente se faz despesas, com as Fortalezas, militar, e Hospital”44. Argumenta que a transferência prejudicaria o andamento dos contratos das baleias e do sal e a cobrança dos respectivos impostos, bem como as “despesas que freqüentemente se precisa fazer em uma Praça, e porto de Mar”45. Lembra o risco da transferência do cofre durante a viagem, tanto por mar quanto por terra, e que em São Paulo ficaria o cofre "ainda mais desamparado em um Sertão aberto”; além disso, exorta ao governador que deveria ele residir em Santos para dar assistência "se houver por algum incidente [uma] Guerra, o que Deus tal não permita”46. 
A marinha destronada: ou a famigerada São Vicente derrotada pela Rochela paulista. A afirmação de São Paulo como cabeça de capitania (1681-1766).

Em carta ao rei de 5 de dezembro de 1767, o governador afirma que a mudança não acarretou nenhum dos inconvenientes apontados pelo provedor, "porque a tudo se deu remédio, e não há outra diferença mais que a girar menos dinheiro na Vila de Santos, e mais nessa Cidade de S. Paulo, em que atualmente fica residindo a dita Provedoria”47. Apesar do parecer contrário do provedor, tanto o cofre quanto o governador sobem a serra em direção a São Paulo, que já não era mais apenas um sertão aberto para as autoridades que governavam a capitania.

Os argumentos dos oficiais santistas e do provedor da Fazenda não sensibilizaram nem ao rei nem ao governador; ainda em 1782, Marcelino Pereira Cleto, ouvidor interino da comarca, juizde-fora de Santos, além de ouvidor e corregedor da comarca do Rio de Janeiro e escrivão do processo da Inconfidência Mineira, apontava a decadência da vila de Santos, onde tudo "era ruínas, e deserção”, tendo ficado a marinha "sem as minas, sem negócio e sem agricultura” (CLETO, 1977, p. 27).

Cleto queixa-se que foram levados para São Paulo o almoxarife, a casa de fundição, o regimento da praça de Santos e dos voluntários reais, os estudos de gramática, filosofia, retórica, ler e escrever, não tendo sido nomeado nenhum professor para a marinha até então, reproduzindo praticamente os mesmos argumentos da câmara de Santos, em 1766 (CLETO, 1977). Aponta, ainda, que os governadores se mantinham em São Paulo mesmo sem uma casa de residência, o que poderia ser providenciado mais facilmente em Santos, no Colégio que fora dos Jesuítas. Daí concluir, assim como os oficiais da câmara santista da vereança de 1766, que a cabeça da capitania deveria ser transferida para Santos, ou voltar para a vila, já que por um espaço de tempo antes da restauração esteve ali um governador submetido ao Rio de Janeiro. Pois sendo a agricultura da marinha mais útil, diz Cleto,

deve cuidar-se mais na sua povoação, que na serra acima, e isto é o contrário do que se tem praticado. Para a cidade de São Paulo, terra do sertão, se levou o governo, a Sé, junta de fazenda, ouvidoria, casa de fundição, o regimento, que era próprio da guarnição da vila, e praça de Santos (...) que estando na cidade de São Paulo isto se povoa, aumenta e enriquece a terra do sertão, e se desfalca a marinha, quando se deveria cuidar mais na sua povoação (CLETO, 1977, p. 21).

Para confirmar sua tese, o ouvidor lembra que o rei D. João III havia restringido a criação de vilas no sertão, que deveriam obedecer a uma distância mínima de seis léguas uma da outra, dando, no entanto, inteira liberdade para a criação de vilas na marinha, do que deduz o autor que o rei “conheceu já a utilidade incomparavelmente maior de se povoar antes a marinha, que o sertão" (CLETO, 1977, p. 21). Um raciocínio que era já letra morta na política da segunda metade do século XVIII, de ampla penetração e urbanização do interior. 
Foi um longo processo no qual São Paulo impôs sua dominância sobre a capitania, que abandona sua denominação de São Vicente para adotar o nome de São Paulo. A denominação de São Paulo sobrepôs-se à antiga Capitania de São Vicente, substituindo seu nome assim como a vila de Piratininga sucedeu a São Vicente na primazia da cabeça das capitanias que receberiam seu nome. Mesmo tendo sido "muito famigerada noutro tempo" (famigerada no sentido de famosa), diz Frei Gaspar da Madre de Deus, era agora, no tempo em que escreve em fins do século XVIII, “tão desconhecida que nem o nome primitivo conserva para memória de sua antiga existência” (MADRE DE DEUS, 1975, p.29).

Antes mesmo de Frei Gaspar, Sebastião da Rocha Pitta já havia chamado a atenção, em 1730, para o fato de que a primeira província que se havia fundado na América portuguesa, “tendo florescido opulenta em fábricas de engenhos e outras lavouras”, no presente não conservasse “sombras de sua grandeza”. E que também “de cabeça da província perdesse a vila de S. Vicente a dignidade que passou à de Santos, e agora está na cidade de S. Paulo” (ROCHA PITTA, 1950, p.100).

Rocha Pitta se espanta que uma vila que não tinha mais do que uma igreja matriz e uma capela de Santo Antônio, pequena e insignificante, tenha se sobrepujado a uma marinha poderosa e rica no passado. No entanto, a centralidade de São Paulo e sua feição de cabeça de um território em expansão vinham se constituindo de forma insuperável.

Aqui cabe recordar a distinção que faz De Seta entre uma cidade capital e uma cidade dominante: a primeira é aquela investida como tal por parte de um governo do povo, de um patriciado, de um Senhor ou de um Estado. A cidade dominante, ao contrário, não recebe esta investidura mas, apesar disso, “desempenha uma função eminente no âmbito do sistema territorial de que faz parte” (DE SETA, 2002, p.193). Antes de tornar-se cabeça, nova esposa entronizada no leito nupcial da capitania restaurada e ressuscitada, São Paulo já exercia sua dominância, como ponta de lança da conquista do sertão e das minas, constituindo um centro importante de construção de um território que se buscava interiorizar cada vez mais.

Ao final do século XVIII as duas funções, de capital e dominância, se confundem numa mesma cidade. Quando da chegada do Morgado de Mateus, o predomínio de São Paulo ainda era contestado pelas vilas que resistiam à sua centralidade, mas em nenhum momento o governador ou o rei tiveram dúvidas de que era ali onde se tecia a trama do poder.

\section{Notas}

\footnotetext{
${ }^{1}$ A documentação revela uma indefinição na denominação das capitanias. Aparecem indistintamente com os nomes de São Vicente, São Vicente e São Paulo, Santos e São Vicente, por exemplo.
} 
A marinha destronada: ou a famigerada São Vicente derrotada pela Rochela paulista. A afirmação de São Paulo como cabeça de capitania (1681-1766).

${ }^{2}$ Cf. em BUENO, (2009, p. 269) uma reconstituição dos limites das capitanias de São Vicente e Santo Amaro, baseada em mapas por satélite.

${ }^{3}$ Rodrigo de Almeida Bastos recorda a inspiração paulina, na Epístola aos Coríntios, da noção de corpo místico: 2006, pp. 7-8.

${ }^{4}$ Rodrigo de Almeida Bastos recorda a inspiração paulina, na Epístola aos Coríntios, da noção de corpo místico: 2006, pp. 7-8.

${ }^{5}$ Sobre a teoria corporativa da sociedade de Antigo Regime é preciso retornar ao clássico de HESPANHA, 1994, p. 297 e ss.

${ }^{6}$ Cf. CALIXTO, 1924, pp. 138 e ss.; MADRE DE DEUS, 1975, pp. 182-225; LEME, 2004, pp. 77 e ss.; SILVA, 2009, pp. 13-9.

${ }^{7}$ Registro de uma carta do marquez de Cascaes para esta Camara. Registro Geral da Camara Municipal de S. Paulo. São Paulo: Archivo Municipal de São Paulo, 1917, v. III, pp. 345-6. Sobre este tema, cf. BLAJ, 2002, p. 32-3.

${ }^{8}$ Registro de provisão que passou o senhor marquez de Cascaes a esta Villa. Ibid., pp. 390-1.

${ }^{9}$ Registro de carta que a Camara de São Paulo escreveu á Camara de São Vicente em os quatro do mez de outubro de 684 annos. Ibid., p. 416.

${ }^{10}$ Registro da carta da Camara de São Vicente. Ibid., pp. 434-5.

${ }^{11}$ Registro da carta do governador geral o Marquez das Minas a essa Camara escripta em 6 de setembro 1684 annos. Ibid., p. 442-443.

${ }^{12}$ Carta para os officiaes da Camara da Capitania de São Vicente. Documentos Históricos. Rio de Janeiro: Bibliotheca Nacional, 1929, v. XI, p. 103.

${ }^{13}$ Carta para o Capitão-mor da Capitania de São Vicente. Ibid., p. 101. Azevedo Marques afirma que São Vicente, por conta da má escolha do local de sua fundação, e pelo progresso de Santos, teve uma rápida decadência, que parece, diz ele, “terminará com a extinção completa da povoação.” MARQUES, 1980, v. 2, p. 250.

${ }^{14}$ Registro de uma petição do capitão Maior Pedro Taques de Almeida e do mandado do ouvidor Diogo Aires de Araújo por donde se deu posse ao capitão Maior hoje o primeiro de março de 1685 annos. Registro Geral da Camara Municipal de S. Paulo. São Paulo: Archivo Municipal de São Paulo, 1917, v. III, p. 447-52.

${ }^{15}$ Apesar de fartamente documentada a retomada da primazia de São Vicente e a revogação da transferência feita pelo marquês de Cascais, Ilana Blaj chama a atenção para o fato de que diversos autores, desde coevos como Pedro Taques de Almeida Pais Leme até trabalhos recentes, tomam o ano de 1681 como a data na qual São Paulo se tornou cabeça da capitania. BLAJ, 2002, p. 33, n. 42. Mesmo trabalhos publicados depois do de Blaj ainda incorrem neste mesmo erro. É o caso, por exemplo, dos de NEVES, (2007, p. 17-18), e BUENO, (2009, p. 270). Bueno cita um foral de 1681 que teria sido "um golpe mortal para os santistas”, uma vez que, “dada a pobreza da vizinha São Vicente”, desempenhara Santos, "as funções de capital da Capitania de S. Vicente". Este foral a que se refere a autora deve ser a provisão do marquês de Cascais que, como vimos, não chegou a ter efeito. Neste momento, embora contestada, São Vicente continua sendo a cabeça da capitania.

${ }^{16}$ Actas da Camara da Villa de S. Paulo. 1679-1700. São Paulo: Archivo Municipal de S. Paulo, 1915, v. VII, p. 202-6 ${ }^{17}$ Ibid., p. 536-7.

${ }^{18}$ Carta Régia creando a Capitania de S. Paulo e Minas do Ouro e nomeando governador da mesma a Antonio de Albuquerque Coelho de Carvalho, - de 9 de novembro de 1709. Documentos Interessantes para a Historia e Costumes de S. Paulo. São Paulo: Archivo do Estado de S. Paulo, 1929, v. XLVII, p. 65.

${ }^{19}$ Registro de uma carta do senhor general Antonio de Albuquerque Coelho de Carvalho governador e capitão general desta villa. Registro Geral da Camara Municipal de S. Paulo. São Paulo: Archivo Municipal de São Paulo, 1917, v. IV, p. 4-5.

${ }^{20}$ Carta de Antonio de Albuquerque Coelho de Carvalho a D. João V. sobre o governo de S. Paulo e Minas do Ouro, de 3 de abril de 1710. Documentos Interessantes para a Historia e Costumes de S. Paulo. São Paulo: Archivo do Estado de S. Paulo, 1929, v. XLVII., p. 68-9.

${ }^{21}$ Carta Régia creando a Capitania de S. Paulo e Minas do Ouro e nomeando governador da mesma a Antonio de Albuquerque Coelho de Carvalho, - de 9 de novembro de 1709. Ibid., p. 65.

${ }^{22}$ Registro de uma carta de Sua Magestade. Registro Geral da Camara Municipal de S. Paulo. São Paulo: Archivo Municipal de São Paulo, 1917, v. IV, p. 73.

${ }^{23}$ A situação sui generis da vila de São Paulo, sendo um domínio senhorial e não da coroa, teria sido responsável para um coevo como Manuel Juan de Morales pelo afluxo de população no final do século XVII, atraídos pela liberdade com que se vivia ali, longe da justiça do rei. Apud SILVA, RUIZ, 2004, p. 102.

${ }^{24}$ Carta de Antonio de Albuquerque Coelho de Carvalho a D. João V, sobre o Porto de Santos ficar pertencendo á nova capitania de S. Paulo e Minas do ouro, - de 3 de abril de 1710. Documentos Interessantes para a Historia e costumes de S. Paulo. São Paulo: Archivo do Estado de S. Paulo, 1929, v. XLVII, p. 70-1.

${ }^{25}$ Arquivo Histórico Ultramarino (Lisboa), São Paulo, cx.1, doc. 84. 
${ }^{26}$ Carta Régia subordinando a praça de Santos ao governo do Rio de Janeiro, - de 18 de maio de 1711. Documentos Interessantes para a Historia e costumes de S. Paulo. São Paulo: Archivo do Estado de S. Paulo, 1929, v. XLVII, p.756.

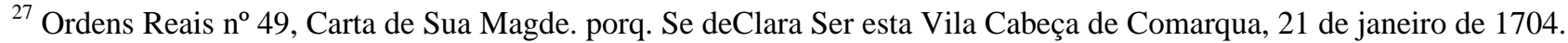
Revista do Arquivo Municipal de São Paulo. São Paulo, I(IV), 1934, p. 68.

${ }^{28}$ Registro de uma provisão de Sua Magestade que Deus guarde ao ouvidor geral. Registro Geral da Camara Municipal de S. Paulo. São Paulo: Archivo Municipal de São Paulo, 1917, v. IV, p. 218.

${ }^{29}$ Documentos Avulsos de Interesse para a História e Costumes de São Paulo. São Paulo: Departamento do Arquivo do Estado de São Paulo, Secretaria de Educação, 1954, v. 5, p. 157

${ }^{30}$ Registro da escriptura de venda, e quitação do donatario pelo marquez de Cascaes á real coroa. Registro Geral da Camara Municipal de S. Paulo. São Paulo: Archivo Municipal de São Paulo, 1917, v. IV, pp. 76 e ss.

${ }^{31}$ Arquivo Histórico Ultramarino (Lisboa), São Paulo, cx. 2, doc. 92.

${ }^{32}$ Arquivo Histórico Ultramarino (Lisboa), São Paulo, cx. 1, doc. 21.

${ }^{33}$ Carta Real annunciando a creação do Bispado de S. Paulo. Documentos Interessantes para a Historia e Costumes de S. Paulo. São Paulo: Archivo do Estado de S. Paulo, 1895, v. XVI, p. 164.

${ }^{34}$ Alvará de creação do novo governo de S. Paulo, - de 2 de dezembro de 1720. Ibid., 1929, v. XLVII, p. 95.

${ }^{35}$ Carta Regia mandando annexar a Praça de Santos á Capitania de S. Paulo. Ibid., 1896, v. XVIII, p. 49-51.

${ }^{36}$ Carta Regia sobre a transferencia para S. Paulo da arrematação dos contractos que se faziam em Santos. Ibid., p. 6364.

${ }^{37}$ Registro de uma carta que os officiaies da Camara escreveram a Sua Magestade que Deus guarde pedindo general e mandaram aqui registrar por mim escrivão. Registro Geral da Camara Municipal de S. Paulo. São Paulo: Archivo Municipal de São Paulo, 1920, v. X, p. 150-3.

${ }^{38}$ Registro de uma carta que os officiaes da Camara escreveram a Sua Magestade fidelissima em vereança de 12 de fevereiro de 1763. Ibid., pp. 470-3.

${ }^{39}$ Documentos Interessantes para a Historia e Costumes de S. Paulo. São Paulo: Archivo do Estado de S. Paulo, 1896, v. XI, p. 209-211

${ }^{40}$ Ibid., 1929, v. XLVII, p. 144.

${ }^{41}$ Carta ao Conde de Oeiras, 20 de junho de 1768. Ibid., 1896, v. XIX, p. 29.

${ }^{42}$ Biblioteca Nacional (Rio de Janeiro). "Demonstração dos principios e das primeiras fundações da Capitania de São Paulo conforme as noticias adquiridas por D. Luís Antônio de Souza Botelho Mourão, governador e capitão-general que foi da dita capitania”. S.d. S.l. Arquivo de Mateus. Doc. 16. I-30, 26, 13.

${ }^{43}$ Arquivo Histórico Ultramarino (Lisboa), São Paulo, Mendes Gouveia, cx. 26, doc. 2445.

${ }^{44}$ Parecer que deo o Provedor da Fazenda Real sobre o Contheudo nesta Junta, 28 de janeiro de 1766. Documentos Interessantes para a Historia e Costumes de S. Paulo. São Paulo: Archivo do Estado de S. Paulo, 1895, v. XV, p. 48.

${ }^{45}$ Ibid., p. 49.

${ }^{46}$ Ibid., p. 50.

${ }^{47}$ Carta $n^{\circ}$ 6. Sobre a mudança do cofre Real de Santos para S. Paulo. Ibid., 1896, v. XXIII, p. 270-271.

\section{Referências}

AMELANG, J. Comparing cities: a Barcelona model? Urban History. Cambridge, UK: Cambridge University Press. 34(2), 2007, p. 173-89.

ARGAN, G. C. Imagem e persuasão. Ensaios sobre o Barroco. Trad. Mauricio Santana Dias. São Paulo: Companhia das Letras, 2004.

BASTOS, R. A. A Ordem Sagrada da República Colonial. Urbana. Revista Eletrônica do CIEC. Campinas: $\quad$ CIEC, $1(1), \quad$ set./dez., $2006 . \quad$ Disponível em http://www.ifch.unicamp.br/ciec/revista/artigos/dossie6.pdf. Consultado em dezembro de 2006.

. Regularidade e ordem nas povoações mineiras no século XVIII. Revista do IEB. São Paulo, 44, p. 27-54, fev., 2007. 
BELLOTTO, H. L. Autoridade e conflito no Brasil: o governo do Morgado de Mateus em São Paulo: 1765-1775. São Paulo: Conselho Estadual de Artes e Ciências Humanas, 1979.

BICALHO, M. F. B. O Rio de Janeiro no século XVIII: a transferência da capital e a construção do território centro-sul da América portuguesa. Urbana. Revista Eletrônica do CIEC. Campinas: IFCH/CIEC, $1(1), \quad$ set./dez., $2006 . \quad$ Disponível em http://www.ifch.unicamp.br/ciec/revista/artigos/dossie1.pdf. Consultado em dezembro de 2006.

BOUZA ÁlVAREZ, F. Lisboa Sozinha, Quase Viúva. A Cidade e a Mudança da Corte no Portugal dos Felipes. Trad. Nuno Miguel Camarinhas. Penélope. Fazer e Desfazer a História. Lisboa, 13, p. 71-93, 1994.

BLAJ, I. A trama das tensões: o processo de mercantilização de São Paulo colonial (1681-1721). São Paulo: Humanitas/FFLCH/USP/Fapesp, 2002.

BLUTEAU, Raphael. Vocabulario portuguez e latino. Coimbra: Collegio das Artes da Companhia de Jesu, 1712. Ed. em CDROM da UERJ.

BRAGA, M. O concurso de Brasília: sete projetos para uma capital. São Paulo: Cosac Naify, Imprensa Oficial do Estado, Museu da Casa Brasileira, 2010.

BUENO, B. P. S. Dilatação dos confins: caminhos, vilas e cidades na formação da Capitania de São Paulo (1532-1822). Anais do Museu Paulista. São Paulo (n. sér.), 17(2), p. 251-94, jul./dez., 2009.

CALIXTO, B. Capitania de Itanhaem. Memoria Historica. Revista do Instituto Historico e Geographico de São Paulo. São Paulo, XX, p. 400-25, 1915.

. Capitanias Paulistas. Revista do Instituto Historico e Geographico de São Paulo. São Paulo, XXI, p. 87-302, 1920.

CAMPBELL, S. The enduring importance of National capital cities in the Global era. Michigan: Workin Papers Series, 2003. Disponível em http://sitemaker.umich.edu/urrcworkingpapers/all_urrc_working_papers/da.data/271896/Paper/urrc 03-08.pdf. Consultado em agosto de 2010.

CLETO, Marcelino Pereira. Dissertação a respeito da capitania de S. Paulo, sua decadencia e modo de restabelecel-a. In: Roteiros e notícias de São Paulo colonial: 1751-1804. Introdução e notas de Ernani Silva Bruno. São Paulo: Governo do Estado, 1977, p. 13-52.

CORTESÃO, J. A fundação de São Paulo, capital geográfica do Brasil. Rio de Janeiro: Livros de Portugal, 1955.

DE SETA, C. La ciudad europea del siglo XV al XX. Orígenes, desarrollo y crisis de la civilización urbana en la Edad Moderna y Contemporánea. Trad. I. Morán García. Madrid: Istmo, 2002.

DERNTL, Maria Fernanda. Método e Arte: criação urbana e organização territorial na capitania de São Paulo, 1765-1811. Tese (Doutorado em História e Fundamentos da Arquitetura e do Urbanismo). São Paulo: FAU/USP, 2010. 
ELLIS, M. São Paulo, de Capitania a Província (pontos de partida para uma história políticoadministrativa da Capitania de São Paulo). Revista de História. São Paulo: FFLCH/USP, 52(103, t. 1), p. 147-216, 1975.

GAMA, A. As capitais no discurso geográfico. Penélope. Fazer e Desfazer a História. Lisboa, 13, p. 9-21, 1994.

HANCOCK, C. Paris et Londres au XIXe siècle. Représentations dans les guides et récits de voyage. Paris: CNRS, 2003.

HESPANHA, A. M. As vésperas do Leviathan. Instituições e poder político em Portugal - séc. XVII. Coimbra: Almedina, 1994.

HOLANDA, S. B. Movimentos de população em São Paulo no século XVIII [XVII]. Revista do IEB. São Paulo, 1, p. 55-111, 1966.

LEME, P. T. A. P. História da Capitania de São Vicente. Brasília: Senado Federal, 2004.

LEPETIT, B. Das capitais às praças centrais. Mobilidade e centralidade no pensamento econômico francês. In: SALGUEIRO, H. A. (Org.). Cidades capitais do século XIX. São Paulo: Edusp, 2001, p. 41-63.

LUÍS, W. Na Capitania de São Vicente. Belo Horizonte: Itatiaia; São Paulo: Edusp, 1980.

MADRE DE DEUS, Frei Gaspar da. Memórias para a história da capitania de São Vicente. Belo Horizonte: Itatiaia; São Paulo: Edusp, 1975.

MARQUES, M. E. A. Apontamentos históricos, geográficos, estatísticos e noticiosos da Província de São Paulo: seguidos da cronologia dos acontecimentos mais notáveis desde a fundação da Capitania de São Vicente até o ano de 1876. Belo Horizonte: Itatiaia; São Paulo: Edusp, 1980. 2 v.

MUSSET, A. Villes nomades du Nouveau Monde. Paris: Éditions de l’École des hautes études en sciences sociales, 2002.

NEVES, C. M. A vila de São Paulo de Piratininga. Fundação e representação. São Paulo: Annablume/Fapesp, 2007.

PITTA, S. R. História da América portuguesa. Rio de Janeiro, São Paulo, Porto Alegre: Jackson, 1950.

RAWAT, R. Capital City Relocation. Global-Local Perspectives in the Search for an Alternative Modernity. Toronto: York University, 2005. Disponível em http://prayaga.org/documents/papercapitalcity.pdf. Consultado em abril de 2010.

RINGROSE, D. R. Capital cities, urbanization, and modernization in early Modern Europe. Journal of Urban History. Thousand Oaks, CA: Sage, 24(2), jan., 1998, p. 155-83.

ROMEIRO, A. Paulistas e emboabas no coração das Minas. Idéias, práticas e imaginário político no século XVIII. Belo Horizonte: UFMG, 2008. 
SILVA, J. T.; RUIZ, R. São Paulo, de vila a cidade: a fundação, o poder público e a vida política. In: PORTA, P. (Org.). História da Cidade de São Paulo. V. 1: a cidade colonial. São Paulo: Paz e Terra, 2004, p. 69-113.

SILVA, M. B. N. (Org.). História de São Paulo colonial. São Paulo: Unesp, 2009.

TORRÃO FILHO, A. O “milagre da onipotência” e a dispersão dos vadios: política urbanizadora e civilizadora em São Paulo na administração do morgado de Mateus (1765-1775). Estudos IberoAmericanos. Porto Alegre: Edipucrs, 31(1), p. 145-65, 2005.

. Paradigma do caos ou cidade da conversão? São Paulo na administração do Morgado de Mateus. São Paulo: Annablume/Fapesp, 2007.

DERNTL, Maria Fernanda. Cidade e civilidade: um governo ilustrado na Capitania de São Paulo In: GAZZANEO, Luiz Manoel (Org.). Da Baixa Pombalina a Brasília. Iluminismo e Contemporaneidade em Países e Espaços de Língua Portuguesa. Cidades e Espacialidade. Rio de Janeiro: UFRJ/FAU/PROARQ, 2010, p. 257-275.

VIANNA, H. Questão Vimieiro-Lumiares. In: São Paulo no Arquivo de Mateus. Rio de Janeiro: Biblioteca Nacional, Divisão de Publicações e Divulgação, 1969, p.103-126.

VIDAL, L. Mazagão, la ville qui traversa l'Atlantique. Du Maroc à l'Amazonie (1769-1783). Paris: Aubier, 2005.

De Nova Lisboa a Brasília: a invenção de uma capital (séculos XIX-XX). Trad. Florence Marie Dravet. Brasília: UnB, 2009.

ZAGARRI, R. Representation and the removal of State Capitals, 1776-1812. The Journal of American History. Lillington, NC, 74(4), mar., 1988, p.1239-1256.

Recebido em: 15/02/2011

Aprovado em: 02/04/2011 